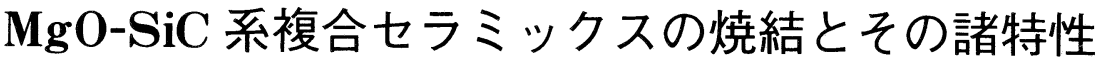

\author{
玉利信幸・近藤功・松浦広隆* · 木下実 \\ ( 大阪工業技術試験所, 563 池田市緑丘 1-8-31 \\ *日東電気工業(株), 567 茨木市下穂積 1-1-2
}

\section{Sintering of MgO-SiC Composite Ceramics and Their Properties}

\author{
Nobuyuki TAMARI, Isao KONDO, Hirotaka MATSUURA* and Makoto KINOSHITA \\ ( Government Industrial Research Institute, Osaka, 8-31, Midorigaoka 1-chome, Ikeda-shi 563 \\ * Nitto Electric Industries Co., Ltd., 1-2, Shimohozumi 1-chome, Ibaraki-shi 567
}

\begin{abstract}
Composite ceramics of $\mathrm{MgO}$ mixed with SiC fine powder up to 90 vol\% were fabricated by the hot-pressing at $1700^{\circ}-1900^{\circ} \mathrm{C}$ under $30 \mathrm{MPa}$ for $30 \mathrm{~min}$. The properties (bending strength, fracture toughness, hardness, oxidation-resistance et al.) of the hot-pressed bodies were measured. Fairly dense $\mathrm{MgO}$-SiC composite ceramics with relative densities above $95 \%$ were obtained in the region of $\mathrm{SiC}$ content up to $50 \mathrm{vol} \%$ at a sintering temperature of $1850^{\circ} \mathrm{C}$. The composites containing 30-50 vol \% SiC had higher strength, hardness and thermal shock resistance than MgO monolithic compacts. Little decrease in the strength was observed at temperatures up to $1400^{\circ} \mathrm{C}$ because of surpressing the fracture of $\mathrm{MgO}$ at grain boundary by $\mathrm{SiC}$ particles. The fracture toughness (about $5 \mathrm{MPa} \cdot \mathrm{m}^{1 / 2}$ ) of composite with a SiC content of 30 vol \% was two and half times as large as that of hot-pressed $\mathrm{MgO}$ at $1400^{\circ} \mathrm{C}$. This is considered to be due to the crack deflection by SiC particles. This composite ceramics showed poor oxidation-resistance, so that the high-temperature uses must be limited in certain range.

[Received July 27, 1988; Accepted September 16, 1988]
\end{abstract}

Key-words : $\mathrm{MgO}, \mathrm{SiC}$, Composite ceramics, Sintering, Properties

\section{1. 緒 言}

マグネシア $(\mathrm{MgO})$ は耐熱性が高く，アルカリや塩 基材料に対する耐食性や高温での電気絶縁性に優れてお り, MHD 発電等の絶縁壁用耐火材料として有望視され ている。しかしながら，この材料は高温強度，破壊靶性 や耐熱衝撃性に乏しい欠点を持つ。これまで $\mathrm{MgO}$ に夕 ングステン金属粒子や炭化ケイ素ウイスカーを複合する ことにより，機械的衝撃性や破壊エネルギーが向上する ことが報告されている11,2).

本研究では $\mathrm{MgO}$ の上記の欠点を改善することを目的 に, $\mathrm{MgO}$ に炭化ケイ素 $(\mathrm{SiC})$ 微粒子を複合し, その 際の焼結性及び得られた複合体の二, 三の特性（強度, 靶性, 硬度, 耐酸化性等) を調べたのでここに報告する。

\section{2. 実験方法}

\section{1 原料及びその調製}

$\mathrm{MgO}$ 粉末は平均粒径 $0.25 \mu \mathrm{m}$ の岩谷化学製の MTK-30 を用いた。一方, $\mathrm{SiC}$ 粉末としてはイビデン 製の $\beta$ 型のものを用いた。この粉末の平均粒径は 0.32 $\mu \mathrm{m}$ である.これらの混合粉末をエ夕ノール中で 24 時 間湿式混合した後乾燥し，16メッシュのふるいを通し たものを焼結に供した． $\mathrm{SiC}$ 添加率は 10，20，30，40， $50 ， 70$ 及び $90 \mathrm{vol} \%$ とした。

\section{2 焼結}

焼結は,上記の混合粉末を黒鉛型枠内に充填し,前もつ て所定の圧力を負荷した後, 昇温速度 $60^{\circ} \sim 70^{\circ} \mathrm{C} /$ 分で 所定温度まで昇温し，ホットプレス終了後は圧力を解放 すると同時に放冷した。ホットプレス条件は，温度 $1700^{\circ} \sim 1900^{\circ} \mathrm{C}$, 圧力 $30 \mathrm{MPa}$ ，及び時間 30 分である. 得られた焼結体は, 約 $20 \times 40 \times 5 \mathrm{~mm}$ の板状である.

\section{3 焼結体の特性測定}

得られた焼結体を\#200のダイヤモンドホイールで研 削し，水中浸せき法によりかさ密度を測定した。

\#800 のダイヤモンド研磨板で引張り面を仕上げした $3 \times 4 \mathrm{~mm}$ 角の試験片を用い, 荷重速度 $0.5 \mathrm{~mm} /$ 分の条 件下， 3 点曲げにより強度試験を行った。この際, 装置 の都合により室温での測定ではスパン $30 \mathrm{~mm}$ で，高温 での測定ではスパン $20 \mathrm{~mm}$ で試験した。 また，高温で の測定では, 試験片をその温度に 10 分間保持した後に 試験を行った。ホットプレスに垂直な試料面を $1 \mu \mathrm{m}$ の ダイヤモンドペーストで鏡面仕上げした後， 9.8 98 N, 30 秒の条件下, IF 法により破壊勒性值を測定した。ま た, 靶性測定の際ビッカース硬度を求めた。弾性率は, $1 \times 4 \times 40 \mathrm{~mm}$ の試験片について曲げ共振法により測定 した.

ホットプレスに垂直な方向が長手になるようにして 3 $\times 4 \times 15 \mathrm{~mm}$ に切り出した試料について，アルミナを標 準試片に用いて空気中, 昇温速度 $10^{\circ} \mathrm{C} /$ 分で $1200^{\circ} \mathrm{C}$ 
までの範囲で熱膨張測定を行った。耐熱衝撃破壊抵抗は $3 \times 4 \times 40 \mathrm{~mm}$ の試験片を用い, 所定温度から水中投下 L.た後, 室温で強度測定を行い求めた。而酸化性の試験 は $4 \times 3 \times 40 \mathrm{~mm}$ の試料を用いて空気中, $1300^{\circ} \mathrm{C}$ で行っ た。

\section{3. 結果と考察}

\section{1 焼結性と室温強度}

図 1 に， SiC 添加率 $40 \mathrm{vol} \%$ までの範囲で，本複合 体のち密化に対する焼結温度と $\mathrm{SiC}$ 添加率の影響を調 ベた結果を示す．X線回折の結果, '本焼結条件下では $\mathrm{MgO}$ と $\mathrm{SiC}$ の間で反応は起こらないことが分かった。 そこで,ここでの相対密度の值は $\mathrm{MgO}$ と $\mathrm{SiC}$ の単純 混合体の理論密度に対するかさ密度の比で表わしてい る. $\mathrm{MgO}$ 及び $\beta-\mathrm{SiC}$ の理論密度はそれぞれ $3.65 \mathrm{~g} / \mathrm{cm}^{3}$ 及び $3.19 \mathrm{~g} / \mathrm{cm}^{3}$ である。本研究で用いた $\mathrm{MgO}$ 単体の場 合は $1300^{\circ} \mathrm{C}$ でのホットプレスでち密化した。これに $\mathrm{SiC}$ を添加するとち密化が阻害され, $\mathrm{SiC}$ 添加量の増 加とともに相対密度は低下したが， $1850^{\circ} \mathrm{C}$ では $40 \mathrm{vol}$ \% 添加でもかなりち密な複合体を得ることができた。 また， $1900^{\circ} \mathrm{C}$ での焼結では， $\mathrm{MgO}$ 単体は良好な成形体 が得られたが，SiCを添加した場合は非常に多孔質な ものしかできなかった。それで，以下の実験では $1850^{\circ} \mathrm{C}$ で作製した複合体の結果について示す。

図 2 に, $\mathrm{SiC}$ を $90 \mathrm{vol} \%$ まで添加し， $1850^{\circ} \mathrm{C}$ で焼成 した複合体の相対密度と室温曲げ強度を示す． SiC 添 加率 $30 \mathrm{vol} \%$ までは十分ち密化しており，50 vol％添 加でも $95 \%$ 程度の密度を持つ成形体が得られた。しか し, $\mathrm{SiC}$ 添加率をこれ以上増やすと急激に密度は低下 した。一方, 室温曲げ強度は, $\mathrm{SiC}$ 添加量の増加とと もに大きくなり, $40 \mathrm{vol} \%$ で最大值 $480 \mathrm{MPa}$ を示した. この值は $\mathrm{MgO}$ 単体において最大の強度值が得られた $1300^{\circ} \mathrm{C}$ 焼結体の強度值（約 $380 \mathrm{MPa}$ ) より高い。この ように $\mathrm{SiC}$ 添加により強度の増加が見られたのは走査

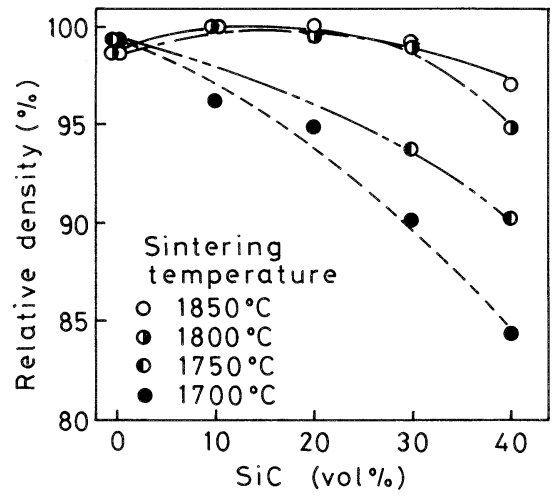

Fig. 1. Effect of sintering temperature and $\mathrm{SiC}$ content on the densification of $\mathrm{MgO}-\mathrm{SiC}$ composite.
型電子顕微鏡 $(\mathrm{SEM})$ 観察より $\mathrm{SiC}$ 添加量の増加に従 い $\mathrm{MgO}$ 粒子の粒成長が抑制された結果と推察される. $40 \mathrm{vol} \%$ 以上の添加では密度の低下のため強度も急激 に低下した。このような結果がサイアロンに SiC を添 加した系においても認められている31.

\section{2 高温曲げ強度}

図 3 に, $\mathrm{MgO}$ 単体と $\mathrm{SiC}$ 添加率 $30 \mathrm{vol} \%$ 及び 50 $\mathrm{vol} \%$ の複合体の高温曲げ強度の結果を示す。ここでの 結果はスパン $20 \mathrm{~mm}$ で測定したため, 図 2 の場合（ス パン $30 \mathrm{~mm}$ ) より若干高い值を示している. $\mathrm{MgO}$ 単体 の場合，高温になると強度が大きく低下し， $1400^{\circ} \mathrm{C}$ で は室温值の $1 / 2$ になった。 また, 最大の室温強度を示し

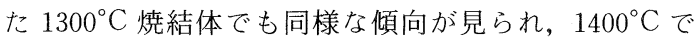
は約 $1 / 3$ まで強度值が低下した。一方，SiC を複合し

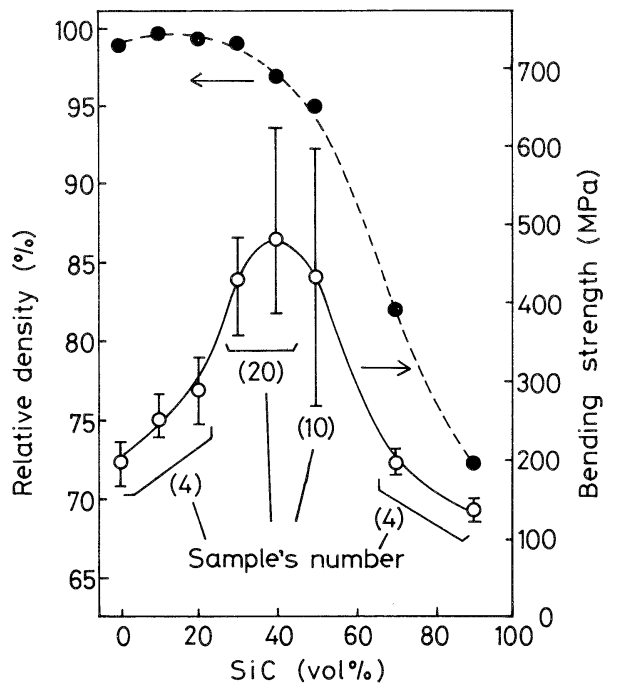

Fig. 2. Relative densities and room temperature bending strength of $\mathrm{MgO}-\mathrm{SiC}$ composite sintered at $1850^{\circ} \mathrm{C}$.

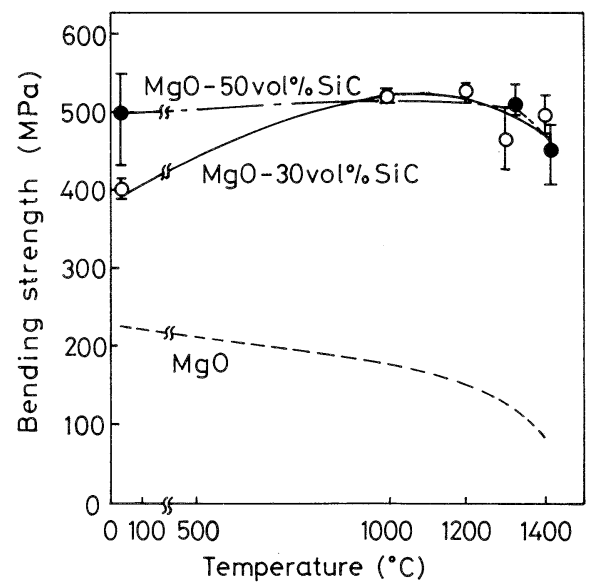

Fig. 3. High temperature bending strength of monolithic $\mathrm{MgO}$ and $\mathrm{MgO}-\mathrm{SiC}$ composites with $30 \mathrm{vol} \%$ or 50 vol \% SiC. 

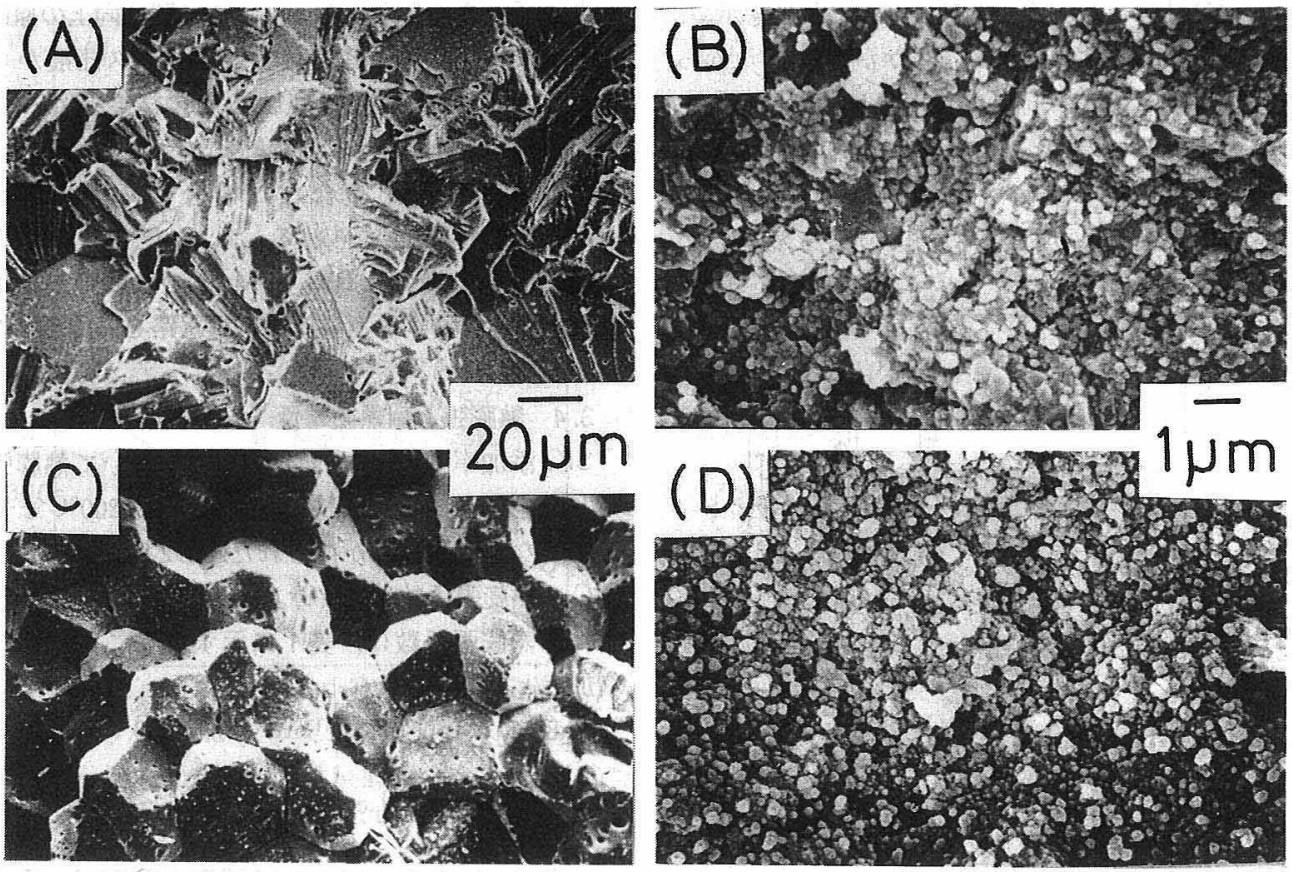

Fig. 4. Fractured surfaces after bending test at room temperature and at $1400^{\circ} \mathrm{C}$ of monolithic $\mathrm{MgO}$, (A) and (C), and $\mathrm{MgO}-\mathrm{SiC}$ composite with $40 \mathrm{vol} \% \mathrm{SiC},(\mathrm{B})$ and (D). Testing temperature; (A), (B) : room temperature, (C), (D) : $1400^{\circ} \mathrm{C}$.

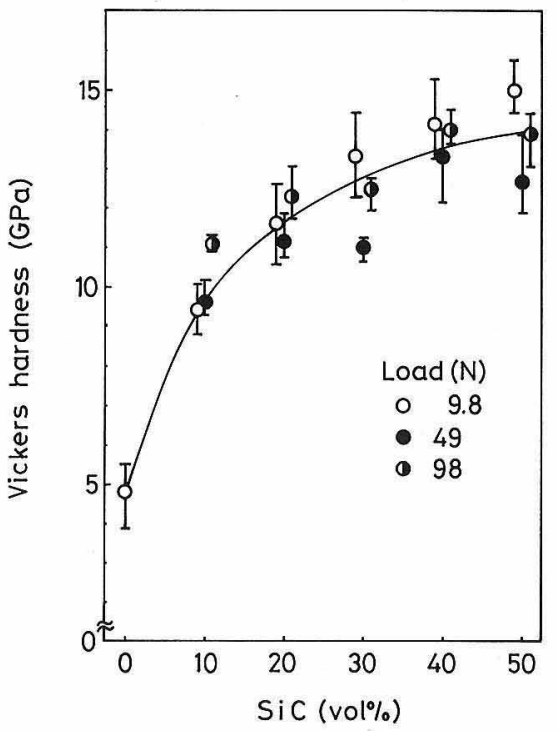

Fig. 5. Vickers hardness of $\mathrm{MgO}-\mathrm{SiC}$ composite with 50 vol $\%$ SiC.

た場合は高温においてもほとんど強度低下がなく， $1400^{\circ} \mathrm{C}$ まで $500 \mathrm{MPa}$ 程度の強度を維持していた. また, $30 \mathrm{vol} \%$ 添加の試料において高温での值が室温より高 いのは, 恐らく高温になると $\mathrm{MgO}$ と $\mathrm{SiC}$ の熱膨張差 による残留応力が緩和される結果と考えられる. $\mathrm{MgO}$
及び $\mathrm{SiC}$ の熱膨張率はそれぞれ $14 \times 10^{-6} / \mathrm{K}$ 及び $4.8 \times$ $10^{-6} / \mathrm{K}$ である。

図 4 に, $\mathrm{MgO}$ 単体と $\mathrm{SiC}$ 添加率 $40 \mathrm{vol} \%$ の複合体 の室温及び $1400^{\circ} \mathrm{C}$ での曲げ試験後の破面を示す. $\mathrm{MgO}$ 単体の場合は，かなりの粒子が粒内破壊しているが，高 温になるとほとんど粒界で破壊している，この粒界破壊 が, $\mathrm{MgO}$ 単体では図 3 に示した高温での強度低下を招 いたと推察される. 一方, $\mathrm{SiC}$ 複合体では室温と高温 においてその破面に違いは見られなかった．また，添加 した $\mathrm{SiC}$ 粒子は焼結することなく, $\mathrm{MgO}$ 粒子の粒界に 分散している様子が認められる.このことより, $\mathrm{SiC}$ 粒子が $\mathrm{MgO}$ の高温での粒界破壊を抑制し，その結果， 複合体では高温強度の低下がほとんど見られなかったと 考えられる.

\section{3 硬度と破壊靶性}

図 5 に, $\mathrm{SiC}$ 添加率 $50 \mathrm{vol} \%$ までの試料のビッカー 不硬度を示す．強度の場合は $40 \mathrm{vol} \%$ で極大を示した が，硬度は测定した $50 \mathrm{vol} \%$ までの範囲では $\mathrm{SiC}$ 添加 量の増加とともに単調に増大し， $50 \mathrm{vol} \%$ 添加では $\mathrm{MgO}$ 単体の值 (約 $5 \mathrm{GPa}$ ) の約 3 倍になった. また, 弾性率も $\mathrm{SiC}$ が $\mathrm{MgO}$ に比べて大きいので $(\mathrm{MgO} ; 281$ $\mathrm{GPa}, \mathrm{SiC} ; 367 \mathrm{GPa})$ ， $\mathrm{SiC}$ 添加率の増加とともに高く なり，10 vol \% で $295 \mathrm{GPa}, 30$ vol \% で $308 \mathrm{GPa}, 50$ vol \% で $321 \mathrm{GPa}$ であった. 
図 6 に, IF 法により測定した破壊勒性の結果を示す. $\mathrm{MgO}$ 単体の場合は荷重 $9.8 \mathrm{~N}$ でしか測定できなかっ た. $\mathrm{SiC}$ の添加は䩲性の向上にも寄与し, $\mathrm{SiC}$ 添加と ともに勒性值は高くなり，30 vol％で最大值，約 5.2 $\mathrm{MPa} \cdot \mathrm{m}^{1 / 2}$ を示した. この值は $\mathrm{MgO}$ 単体の值の約 2.5 倍である.これ以上の添加ではち密化が十分でないため

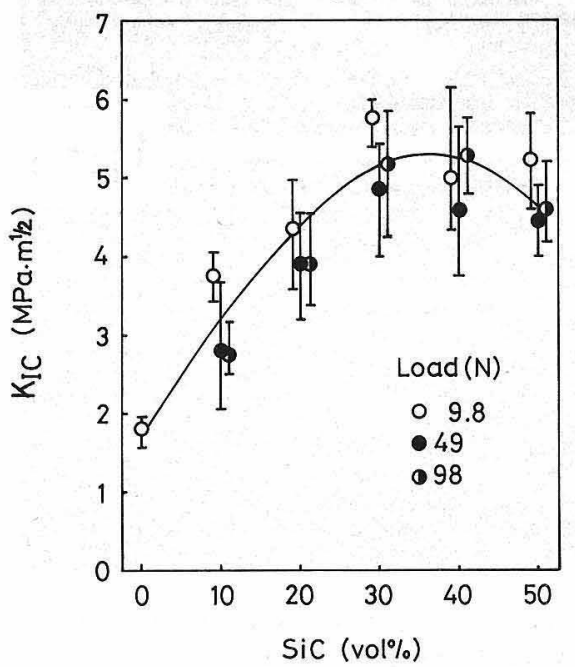

Fig.6. Fracture toughness of the specimen shown in Fig. 5.
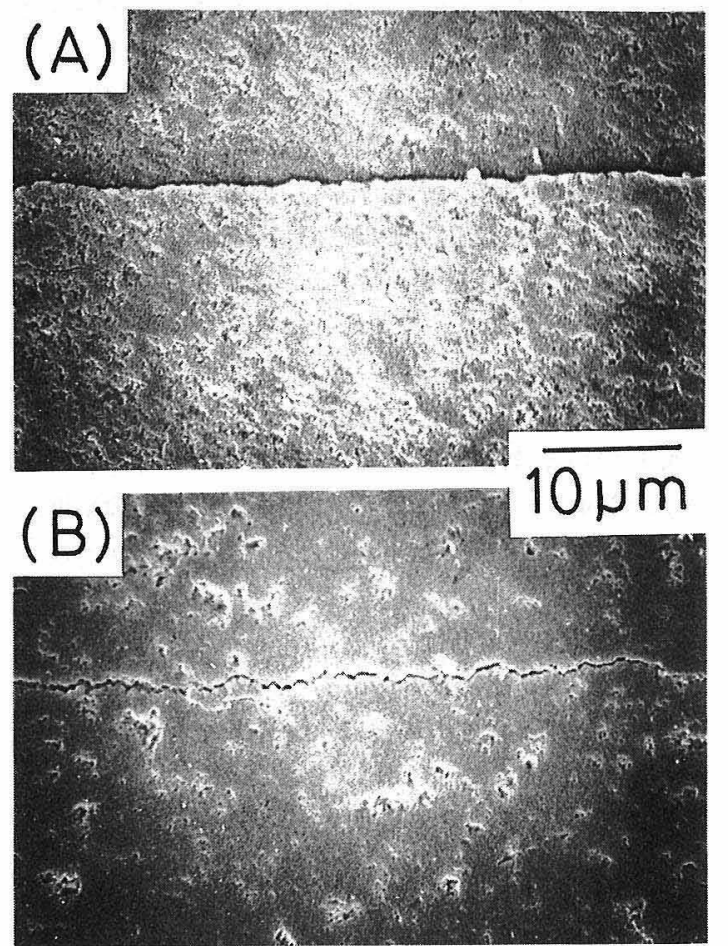

Fig. 7. Crack propagation from corner of Vickers indentation in monolithic $\mathrm{MgO},(\mathrm{A})$, and $\mathrm{MgO}-\mathrm{SiC}$ composite with $40 \mathrm{vol} \% \mathrm{SiC}$, (B).
か若干低下する傾向にあった.この鞀性向上の原因を探 るため $\mathrm{MgO}$ 単体と複合体のビッカース圧痕からのク ラックの進展の様相を観察した.その結果を図 7 に示す. $\mathrm{MgO}$ 単体の場合はほぼ直線的にクラックが進展してい るが， $\mathrm{SiC}$ 粒子を複合した場合はクラックの湾曲 (deflection) が認められる. したがって，本複合体に おける䩲性の増大は $\mathrm{SiC} と \mathrm{MgO}$ の熱膨張差により生 じた残留応力が,クラックの伝播経路を湾曲させた結果 と考えられる.

\section{4 熱膨張と耐熱衝撃性}

$\mathrm{SiC}$ 添加率 $50 \mathrm{vol} \%$ までの試料について熱膨張を測

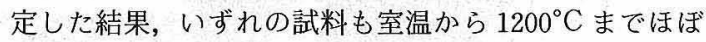
直線的な熱膨張曲線が得られた. 3.2 節に示したように $\mathrm{SiC}$ の熱膨張係数が $\mathrm{MgO}$ よりかなり小さいので，本複 合体の熱膨張係数は, 表 1 に示すように $\mathrm{SiC}$ 添加量の 増加とともに小さくなった。

図 8 に, $\mathrm{MgO}$ 単体と $\mathrm{SiC}$ 添加率 $40 \mathrm{vol} \%$ の複合体

Table 1. Thermal expansion coefficient of $\mathrm{MgO}-\mathrm{SiC}$ composite.

\begin{tabular}{cc}
\hline $\begin{array}{c}\text { Sic content } \\
\text { (vol\%) }\end{array}$ & $\begin{array}{c}\text { Linear thermal } \\
\text { coefficient } \\
\left(\times 10^{-6} / \mathrm{K}\right)\end{array}$ \\
\hline 0 & 14.4 \\
10 & 13.3 \\
20 & 12.0 \\
30 & 11.0 \\
40 & 9.9 \\
50 & 9.0 \\
\hline
\end{tabular}

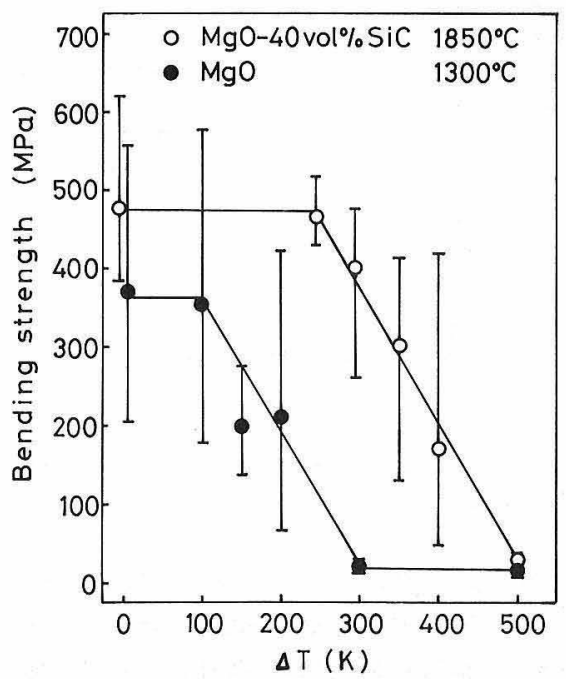

Fig. 8. Bending strength of monolithic $\mathrm{MgO}$ and $\mathrm{MgO}-\mathrm{SiC}$ composite with $40 \mathrm{vol} \% \mathrm{SiC}$ after water quenching. 


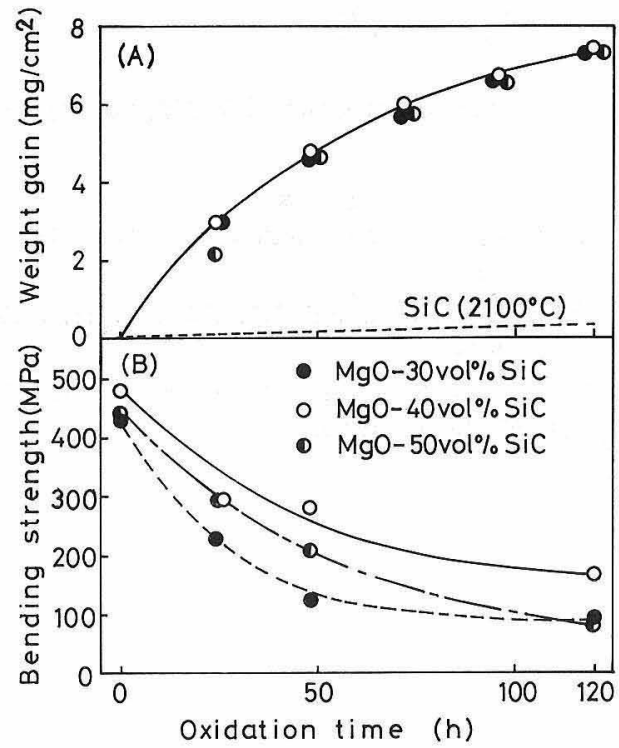

Fig. 9. Weight gain, (A), and bending strength, (B), of $\mathrm{MgO}-\mathrm{SiC}$ composite after heating at $1300^{\circ} \mathrm{C}$ in air.

の耐熱衝撃試験の結果を示す. $\mathrm{MgO}$ 単体の場合は温度 差 $100 \mathrm{~K}$ から強度低下が生じた。一方，本複合体では 表 1 に示したようにその熱膨張係数が小さいことや 3.3 節で述べたように鞀性がかなり改善されていることなど が影響して臨界温度差が $250 \mathrm{~K}$ まで向上した。

\section{5 而酸化性}

次に，本複合体について空気中， $1300^{\circ} \mathrm{C}$ で耐酸化性 の試験を行った．図9(A) にその際の酸化増量の測定 結果を, 図 $9(B)$ に酸化試験後の強度測定の結果を示す。 図 9(A) の破線は， $2100^{\circ} \mathrm{C}$ で焼結したち密な $\mathrm{SiC}$ 成形 体について同じ条件下で測定した結果である。 $\mathrm{SiC}$ 成 形体に比べて本複合体は酸化増量がかなり多く，その量 は $\mathrm{SiC}$ 添加率 30,40 ,及び $50 \mathrm{vol} \%$ の試料の間ではほ とんど差は見られなかった。また， $\mathrm{SiC}$ を $40 \mathrm{vol} \%$ 添 加した試料の酸化膜の厚さを測定してみると 24 時間で $13 \mu \mathrm{m} ， 48$ 時間で $18 \mu \mathrm{m} ， 120$ 時間で $30 \mu \mathrm{m}$ であった. 酸化試験後の強度は, 酸化時間とともに酸化膜の厚さが 大きくなるに従い低下し，120 時間後には $1 / 3$ 加ら $1 / 4$ になった．測定した複合体のなかでは室温強度の一番高 かった $40 \mathrm{vol} \%$ 添加のものが酸化後も高い值を示した.

図 10 に, SiC 添加率 $40 \mathrm{vol} \%$ の試料の 120 時間酸化 後の表面と断面の様相を示す. 形成された酸化膜は $\mathrm{X}$ 線回折の結果 $\mathrm{MgSiO}_{3}$ (エンスタタイト) であった。し たがって，本酸化膜は次のような過程を経て形成された と推察される.

$$
\begin{aligned}
& \mathrm{SiC}\left[+\mathrm{O}_{2}\right] \rightarrow \mathrm{SiO}_{2}\left[+\mathrm{CO}_{2}\right] \\
& \mathrm{SiO}_{2}+\mathrm{MgO} \rightarrow \mathrm{MgSiO}_{3}
\end{aligned}
$$

図 10 から形成された酸化膜の粒子は 20 ないし $30 \mu \mathrm{m}$
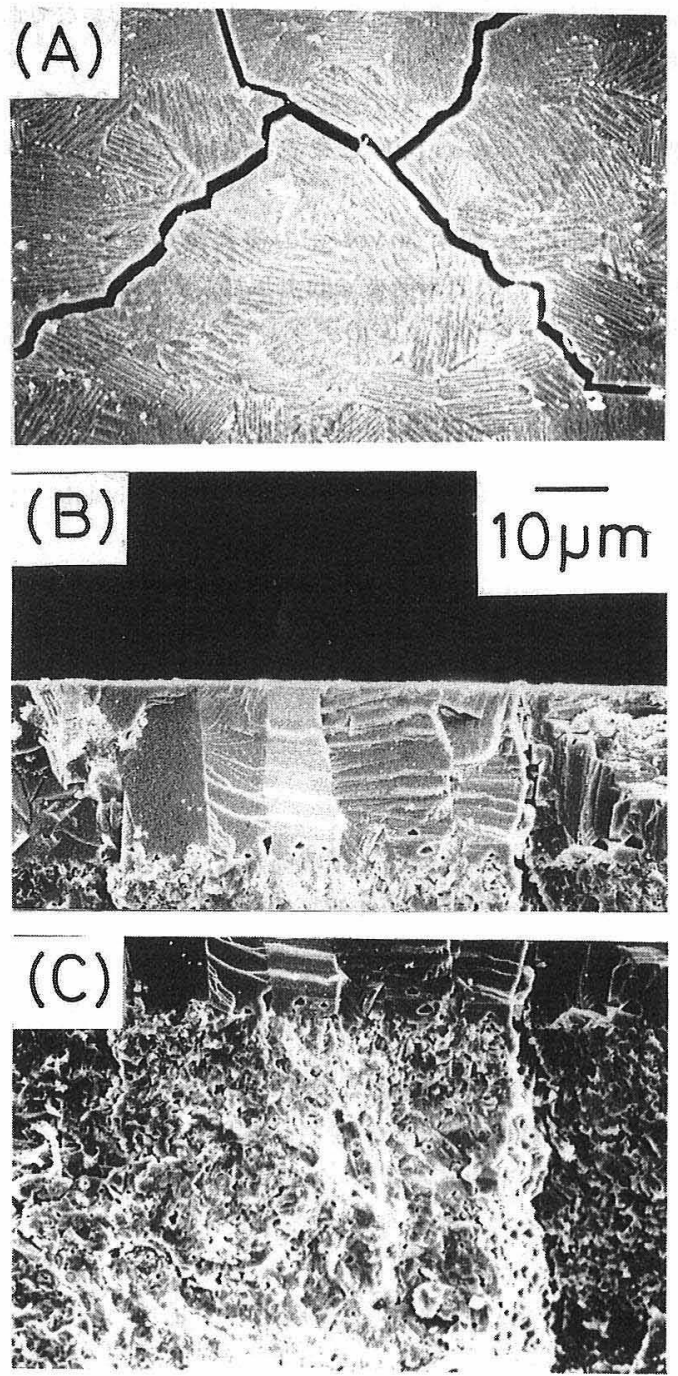

Fig. 10. Appearance of surface, (A), and crosssections, (B) and (C), of $\mathrm{MgO}-\mathrm{SiC}$ composite with $40 \mathrm{vol} \% \mathrm{SiC}$ after heating for $120 \mathrm{~h}$ at $1300^{\circ} \mathrm{C}$ in air.

と大きく粒成長しており，また，下地と酸化膜の熱膨張 差のせいか酸化膜の各所において大きなクラックが発生 していることが分かる．このような状態が酸化後の大き な強度低下の原因と考えられる。

\section{4. 結 語}

$\mathrm{MgO}-\mathrm{SiC}$ 系複合セラミックスのホットプレスによる 焼結性と機械的性質及び熱的性質を調べた結果，次の知 見を得た。

（1） $1850^{\circ} \mathrm{C}-30$ 分の条件でホットプレス成形するこ とにより， $\mathrm{SiC}$ 添加率 $50 \mathrm{vol} \%$ までは相対密度 $95 \%$ 以上のかなりち密な $\mathrm{MgO}-\mathrm{SiC}$ 系複合体が得られた。

（2） $\mathrm{SiC}$ 粒子を 30～50 vol \% 添加することにより 
$\mathrm{MgO}$ 単体に比べて強度, 硬度, 耐熱衝撃性をかなり改 善できた。

（3）高温強度については $\mathrm{SiC}$ 粒子が $\mathrm{MgO}$ の粒界 破壊を抑制するため $1400^{\circ} \mathrm{C}$ まで室温值と同程度の值を 示した。

(4) $\mathrm{SiC}$ 添加率 $30 \mathrm{vol} \%$ の複合体の破壊鞀性は $\mathrm{MgO}$ 単体の值の 2.5 倍まで向上した.これは添加した $\mathrm{SiC}$ 粒子によるクラックのデフレクションに起因して いると推察された。

（5）本複合体は耐酸化性が弱く, 空気中, 高温での
使用には問題があることが分かった。

(1988 年 1 月第 26 回窯業基礎討論会発表)

\section{文 献}

1) M. Chappel and R.S. Millman, J. Mater. Sci., 9, 1933-48 (1974).

2) 西田俊彦, 塩野剛司, 山内博之, 西川友三, 材料, 36, 17-21 (1987).

3）梅林正気, 中村 浩, 谷 英治, 岸 和司, 小林和夫, 穼協, 93，162-63 (1985). 